\title{
Isolation, identification, and characterization of phosphate solubilizing bacteria, Paenibacillus sp., from the soil of Danum Valley Tropical Rainforest, Sabah, Malaysia
}

\author{
HERMAN UMBAU LINDANG, VIJAY KUMAR SUBBIAH, KENNETH FRANCIS RODRIGUES, \\ CAHYO BUDIMAN \\ Biotechnology Research Institute, Universiti Malaysia Sabah, 88400 Kota Kinabalu, Sabah, Malaysia. Tel.: +60-88320000; Fax.: +60-88329247 \\ vemail: cahyo@ums.edu.my
}

Manuscript received: 15 June 2021. Revision accepted: 24 September 2021.

\begin{abstract}
Lindang HU, Subbiah VK, Rodrigues KF, Budiman C. 2021. Isolation, identification, and characterization of phosphate solubilizing bacteria, Paenibacillus sp., from the soil of Danum Valley Tropical Rainforest, Sabah, Malaysia. Biodiversitas 22: 43704378. Phosphorus (P) is a vital element for plant growth. However, only $0.1 \%$ of available soil phosphate is directly utilized by plants. Consequently, $\mathrm{P}$ fertilizer, which is mostly sourced from unrenewable resources of phosphate rock, is practically added into croplands. Furthermore, as the demand for this fertilizer increases, its availability and impact on environmental issues raise wide concerns. The use of soil phosphate solubilizing bacteria (PSB) is a promising alternative to be further developed as a biofertilizer to increase the availability of $\mathrm{P}$ elements for plant growth. As such, we report here on our efforts to screen and characterize novel PSB from tropical rainforest soil. The soil samples were collected from the Danum Valley tropical rainforest, which is located in Sabah, at the northeastern region of Borneo. Phosphatase solubilizing bacteria were then screened using the NBRIP agar selective media. The result yielded five colonies, designated as PSB1, PSB2, PSB3, PSB4, and PSB5, displaying halos with an average diameter of 10mm. The 16S rRNA gene sequence analysis using BLASTn indicated that PSB1, PSB2, PSB3, PSB4, and PSB5 were mainly Bacillus sp. PSB01 (MZ675820), Pseudomonas oryzyhabitans PSB02 (MZ675821), Staphylococcus pasteuri PSB03 (MZ675822), Paenibacillus sp. PSB04 (MZ675823), and Staphylococcus pasteuri PSB05 (MZ675824), respectively. Consequently, since Paenibacillus has been reportedly used in the global agriculture industry as a promising biofertilizer, we then selected Paenibacillus sp. PSB04 for further downstream characterization using Gram staining and scanning electron microscope (SEM). The Gram staining revealed that Paenibacillus sp. PSB04 was a Gram-negative bacterium with a rod shape, which was in good agreement with the SEM data. Further analysis revealed that the specific phosphatase activity of the extracellular fraction of this bacterium was 7,378.12 $\mathrm{U} \mathrm{mg}^{-1}$. This was the highest activity observed when compared to previous studies. The results here provide an early insight into an excellent phosphate-solubilizing bacterium obtained from a tropical rainforest which could be beneficial to the agriculture industry.
\end{abstract}

Keywords: Danum Valley, Paenibacillus, phosphatase, phosphate solubilizing bacteria, soil bacteria

Abbreviations: DNA: Deoxyribonucleic acid; DV: Danum Valley; PDB: Protein Data Bank; PSB: Phosphate solubilizing bacteria; P: Phosphorus; SDGs: Sustainable Development Goals; SEM: Scanning Electron Microscope

\section{INTRODUCTION}

By the year 2050, the global food demand and the phosphorus (P) input into croplands are expected to increase by $70 \%$ and $86 \%$ respectively. Moreover, developing countries will likely increase the use of fertilizer, including $\mathrm{P}$, to meet the growing agriculture demand and supply (Hunter et al. 2017; Mogollón et al. 2018). Chemical $P$ fertilizers are known as the product of mining non-renewable sources of rock phosphate minerals. Due to the expected global food demand, the cost of production is expected to rise due to the scarcity of rock phosphate minerals, which is the primary source of $\mathrm{P}$ fertilizer (Hunter et al. 2017). As a result of the challenges to the global community, stakeholders have developed strategies and policies to address the problems, such as the United Nation Sustainable Development Goals (SDGs), which were established in 2012 (Campagnolla et al. 2019). As stated in the SDGs of the 2030 Agenda for Sustainable
Development, harnessing microbes as a biofertilizer agent to control the critical $\mathrm{P}$ macronutrient requirement for plant growth is one of the proposed long-term solutions.

An abundance of $60-70 \%$ of the $\mathrm{P}$ element that is available in the soil exists in both organic and inorganic forms. However, only $0.1 \%$ of the available soil phosphate is ready for direct uptake by plants. The remaining phosphate requires assistance from phosphate solubilizing microorganisms to produce inorganic forms of free solubilizing phosphate (Sharma et al. 2013). In nature, plants need the aids of the microbial community to mineralize and solubilize both forms of phosphate (Ushio et al. 2010). Lowering the $\mathrm{pH}$ of the soil, enhancing chelation of cations bound to the available phosphate, and forming soluble complexes with the metal ions associated with the insoluble available $\mathrm{P}$ are some of the processes used to solubilize the available inorganic forms. Chemical substrates were used in the techniques to overcome the negative effects. Even though chemical fertilizers have 
been proven to increase the availability of soluble $\mathrm{P}$ in the agricultural soil, but it has long-term adverse effects on the soil, surface water, and estuaries due to its chemical impurities (Komatsuzaki and Ohta 2013). Meanwhile, nonspecific acid phosphatases, alkaline phosphatases, and phytases formed naturally by microbes are responsible for the solubilization of organic phosphate by mineralization.

The synergistic relationships between plants and microbial communities in soil have been the key factor to keep the ecosystem in balance. The microbial community is able to use the $\mathrm{P}$ content in soil by producing phosphate solubilizing enzymes and solubilize the inorganic compound of $\mathrm{P}$. The profile of bacterium producing phosphate solubilizing enzymes, or namely phosphatesolubilizing bacteria (PSB), are related to physical, chemical, and biological characteristics of the soil. The most commonly identified PSB belong to the genera of Pseudomonas, Rhizobium, Aspergillus, Bacillus, Staphyloccocus, Paenibacillus, and Penicillium (Suliasih and Widawati 2005; Hii et al. 2020). Their distribution and diversity in the soil are influenced by factors such as soil type, total biomass, plant type, and nutrient accessibility (Tripathi et al. 2012; Pathania et al. 2020). Interestingly, Paenibacillus has the potential to not only able to solubilize phosphate but has nitrogen-fixation ability, antibacterial capacities, release siderophores, and producing indole acetic acid phytohormone (Grady et al. 2016; Liu et al. 2019). These are the essential traits of plant growth-promoting bacteria to facilitate the sustainable development of agriculture goals as biofertilizers. Accordingly, there have been wide attempts to screen and isolate PSB from various sources. Besides, the study on the diversity of PSB is considered as one of the key elements in conservation through understanding sulfur cycling in the ecosystems (Alori et al. 2017).

Danum Valley (DV) is an old-growth primary tropical rainforest in Sabah, Malaysia, with ultisols soils and a yearround low concentration of extractable phosphorus (Green et al. 2005). Accordingly, it is postulated that the phosphatase-producing bacteria are highly abundant in the tropical rainforests of Borneo such as the primary rainforest of DV. As such, it is thought that PSB is widespread in Borneo's tropical rainforests, such as the DV primary rainforest. The dipterocarp rainforest of DV, which is mostly lowland, is a possibly strong source of PSB. The predominantly lowland dipterocarp rainforest of DV may serve as a good source of PSB. Thus, it is hypothesized that DV could harbour diverse microorganisms producing phosphate solubilizing enzymes that can withstand the complex soil condition. It is believed that the native bacteria exhibit unique biological traits and enzymatic activities. Using a metagenomic and direct DNA amplification technique, previous attempts to profile microorganisms from rainforest soil in Sabah discovered some novel bacteria that may be involved in $\mathrm{P}$ solubilization (Tin et al. 2017). Despite this, no attempts have been made to isolate and characterize these bacteria further. Accordingly, this study aims to screen and characterize novel PSB from the tropical rainforest soil.
This report described the first PSB isolated from DV tropical forest soil which was then morphologically and molecularly characterized. The detail on the extracellular alkaline phosphatase enzymatic activity of the selected bacteria was also further characterized. As a result, the findings of this study include an early insight into culturable PSB for future utilization on biofertilizers.

\section{MATERIALS AND METHODS}

\section{Study site and sampling methods}

The study site was located at DV, Sabah, Malaysia whereby, two existed carbon plots designed by the previous study were selected as the sampling plots to collect the soil samples (Riutta et al. 2018). The plot had a planimetric area of 1 ha and was divided into several subplots of $20 \mathrm{~m} \mathrm{x}$ 20m namely Danum Carbon 1 and Danum Carbon 2. Danum Carbon $1\left(4.951^{\circ}, 117.796^{\circ}\right)$ represent steep slope soil topography, and Danum Carbon $2\left(4.953^{\circ}, 117.793^{\circ}\right)$, represent flat soil topography. In this study, 5 subplots were selected from the 2 establish carbon plot. Three sets of $50 \mathrm{~g}$ subsurface soil samples were collected at a $1 \mathrm{~m}$ distance from the center of the subplot. The soil was taken using a hand auger. The soil samples were kept at $4^{\circ} \mathrm{C}$ storage in the field center and were transferred to the laboratory for storage at $-80^{\circ} \mathrm{C}$ within 24 hours until further analysis (Pepper and Gerba 2015; Taylor and Williams 2010).

\section{Bacterial isolation}

The screening and isolation of PSB were done based on the procedures done by Nautiyal (1999) and Mohamed et al. (2019). Firstly, the $5 \mathrm{~g}$ of soil was suspended with $20 \mathrm{ml}$ of autoclaved MiliQ water and was agitated for 1hour at $30^{\circ} \mathrm{C}$. The samples were then spread on National Botanical Research Institute's phosphate (NBRIP) growth agar media containing (per litre): $15 \mathrm{~g}$ agar, $10 \mathrm{~g}$ glucose, $5 \mathrm{~g} \mathrm{MgCl}_{2}$ (Hydrated), $0.25 \mathrm{~g}^{\mathrm{MgSO}_{4}}$ (Hydrated), $0.2 \mathrm{~g} \mathrm{KCl,} 0.1 \mathrm{~g}$ $\left(\mathrm{NH}_{4}\right)_{2} . \mathrm{SO}_{4}, 5 \mathrm{~g} \mathrm{Ca}_{3} \mathrm{PO}_{4}$ (Nautiyal 1999). The plates were incubated at $30^{\circ} \mathrm{C}$ for 7 days. Identification of PSB was done by observing the formation of a halo zone around the colony as it reflects the hydrolysis reaction of tricalcium phosphate in the media. Meanwhile, well plate screening was also done to determine the size of the halo zone $(\mathrm{mm})$. The colonies of dissimilar morphotypes that appeared on the NBRIP agar were purified and long-term storage was performed via cryopreservation with $25 \%$ (v/v) glycerol at $-80^{\circ} \mathrm{C}$ until further analysis.

\section{Morphology identification and characterization}

Morphology and Gram characterization of five isolates were also done to further characterize the isolates. For morphology identification, the bacteria were grown in Nutrient Broth (Oxoid Ltd., Hampshire, United Kingdom) at $37^{\circ} \mathrm{C}$ for 16 hours. The potential candidates were then sub-cultured on a new agar plate and observed under the microscope. All isolates were subjected to Gram staining identification using Gram staining reagent kit (SigmaAldrich, St. Louis, USA). Meanwhile, the selected bacterium 
was then subjected to morphological characterization using scanning electron microscopy (SEM). For this purpose, the gold-coated specimen was prepared according to Arief et al. (2015) and further observed under electron microscope Hitachi S-3400 (Hitachi Ltd, Chiyoda, Tokyo, Japan) at an accelerating voltage of $10 \mathrm{kV}$.

\section{Molecular characterization and phylogenetic analysis of bacteria}

Freshly grown pure bacterial culture in Nutrient Broth media was subjected to genome extraction using QIAamp DNA Mini Kit (Qiagen, Hilden, Germany) according to manufacturer's instruction. The quantity and integrity of the extracted DNA were determined by agarose electrophoresis and Nanodrop spectrophotometry (Thermo Fisher Scientific, Massachusetts, USA).

The polymerase chain reactions (PCR) were performed using NEB Taq PCR (NEB, England) according to the manufacturer's protocol to amplify the conserved bacterial 16S rRNA gene. The components of PCR cocktail mixtures were 1x PCR Buffer, $0.2 \mathrm{mM}$ dNTPs, $5 \mathrm{mM} \mathrm{MgCl}_{2}, 0.5 \mathrm{uM}$ of Forward BSF8' and Reverse BSR1541 Primers and 2.5 units/ $\mu 1$ of Taq DNA polymerase in $50 \mu$ l PCR reaction solution. Primer pairs, namely BSF8 (5'-AGA GTT TGA TCC TGG CTC AG-3') and primer BSR1541 (5'- AAG GAG GTG ATC CAG CCG CA-3') were used as the forward and reverse primers, respectively. PCR was carried out using a Bio-Rad Thermal Cycler (Bio-Rad, California, USA) according to the following program: Initial denaturation at $94^{\circ} \mathrm{C}$ for $2 \mathrm{~min}$; then 30 cycles of denaturation at $98^{\circ} \mathrm{C}$ for $10 \mathrm{sec}$, annealing at $49^{\circ} \mathrm{C}$ for 30 sec and extension at $68^{\circ} \mathrm{C}$ for $30 \mathrm{sec}$ for the amplification of the full length of $16 \mathrm{~S}$ rRNA gene. PCR products were resolved by electrophoresis on $1 \%$ agarose gels and visualized on a GelDoc Go Imaging System (Bio-Rad, California, USA). The band of interest was then excised, purified using QIAquick Gel (Qiagen, USA) extraction kit and sequenced using BigDye Terminator v3.1. Sequencing services were provided by Firstbase Laboratories Sdn Bhd., Selangor, Malaysia.

The identification of the bacterial isolates and determination of their evolutionary relationships were done using the gene sequences. The essential reference sequences were sourced from the NCBI GenBank database. Prior to phylogenetic tree construction, the sequences were aligned by ClustalW and the BLASTn search program was performed to compare the sequences. The phylogenetic analysis was done using molecular evolutionary genetics analysis (MEGA) software version 10 (Stecher et al. 2020). Meanwhile, the reported phosphate enzyme was obtained from the Protein Data Bank database and the accession number was listed (Berman et al. 2000). The nucleotide sequences of the isolated bacteria were deposited in GenBank (https://www.ncbi.nlm.nih.gov/genbank).

\section{Determination of alkaline phosphatase activity}

Each bacterial isolate was determined for its phosphate solubilization ability through the phosphatase assay method according to Chu et al. (2019) with slight modification. The selected bacterium was inoculated in a $250 \mathrm{ml}$ flask comprising $100 \mathrm{ml}$ of Nutrient broth medium and incubated for $16 \mathrm{hr}$ at $37^{\circ} \mathrm{C}$. The overnight cultured was subjected to centrifugation at $10,000 \times g$ for $10 \mathrm{~min}$. The cell-free supernatant sample was collected for alkaline phosphatase (ALP) assay. The activity of ALP was assayed using a colourless substrate $p$-nitrophenyl phosphate ( $p$-NPP) as per the method, which yielded yellow $p$-nitrophenol ( $p$ $\mathrm{NP}$ ). The reaction mixture contained: $1 \mathrm{ml}$ of $5 \mathrm{mM}$ pNPP, $1 \mathrm{ml}$ of $10 \mathrm{mM}$ Tris Buffer, $1 \mathrm{ml}$ of the crude enzyme, and fixed to a final volume of $5 \mathrm{ml}$ with sterile MiliQ water. After incubation at $37^{\circ} \mathrm{C}$ for $60 \mathrm{~min}$, and the reaction was stopped by adding $3.0 \mathrm{ml}$ of termination buffer $(0.1 \mathrm{M}$ $\mathrm{NaOH}$ and $5 \mathrm{mM}$ EDTA). Finally, the absorbance at $405 \mathrm{~nm}$ was measured by GENESYS20 Visible Spectrophotometer (Thermo Scientific, United States of America). One unit (U) of phosphatase activity was defined as the amount of enzyme required to produce $1 \mu$ mole of $p$-NP per minute at $37^{\circ} \mathrm{C}$.

\section{RESULTS AND DISCUSSION}

PSB were found in DV soil samples. The isolated PSB were confirmed by the development of a halo zone around the colony, as seen in Figure 1. The halo zone formed as a by-product of the tri-calcium phosphate hydrolysis reaction in the medium. Initially, numerous colonies were grown on the agar media, but only PSB were subjected to further purification characterization of isolates. The screening revealed five distinct colonies with halos averaging $10 \mathrm{~mm}$ in diameter among these isolates. The halo zone was observed from 4 days and kept increasing in its size until 7 days. Halos in the $5-10 \mathrm{~mm}$ range were commonly used as a baseline for determining potential PSB by other researchers (Bononi et al. 2020). The previous study shows the screening of $\mathrm{P}$ solubilizing activity varied across bacteria species, and typically $16 \mathrm{hr}$ to $72 \mathrm{hr}$ incubation time for bacteria from forest soil (Song et al. 2021; Sánchez-Cruz et al. 2020; Cabugao et al. 2017). Nonetheless, this discovery revealed that tropical rainforest soil contains culturable PSB that are similar to PSBs found in other types of soil (Tang et al. 2020).

Further, Gram staining revealed that PSB1, PSB2, and PSB4 were found to be Gram-negative rod-shaped bacteria, while PSB3 and PSB5 were Gram-positive coccus-shaped bacteria (Figure 2). There is no consensus so far on the types of Gram bacteria dominance of PSB. Billah et al. (2019) reported that PSB may originate either from a group of Gram-positive or negative bacteria. Subsequently, molecular characterization was done for species identification by looking at the sequence of its $16 \mathrm{~S}$ rRNA gene. PCR successfully amplified the $16 \mathrm{~S}$ rRNA band from the isolated PSB at the expected size of around 1,500 bp (Figure 3). The primers used in this study were chosen in order to obtain the full-length of $16 \mathrm{~S}$ rRNA. Sabat et al. (2017) reported that the use of a full-length sequence of the $16 \mathrm{~S}$ rRNA gene has proven to be a useful molecular target for bacterial identification since it may cover the variable region among the species. 



Figure 1. Formation of a clear zone around the isolated bacterium (A)PSB1, (B)PSB2, (C)PSB3, (D)PSB4, (E)PSB5, and (F)Negative Control on NBRIP media 7 days after incubated at $30^{\circ} \mathrm{C}$.
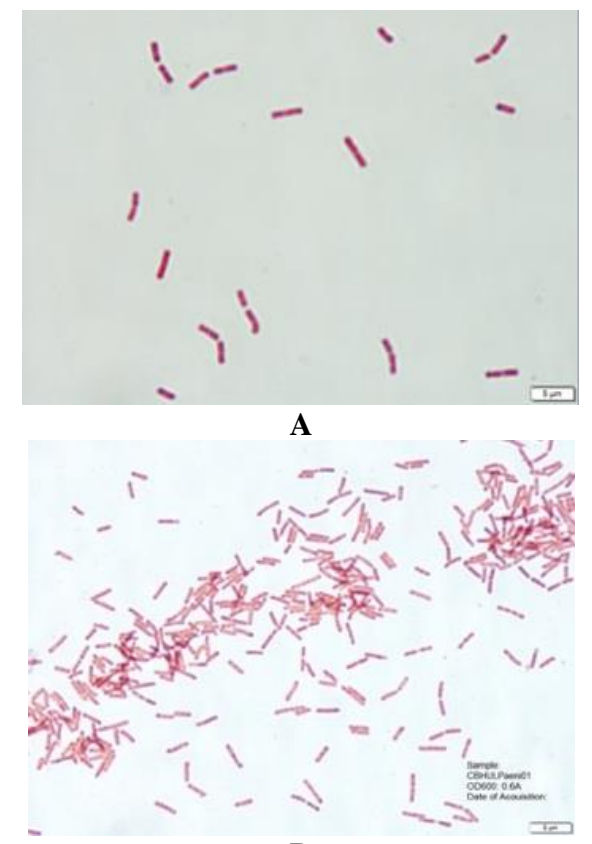

D
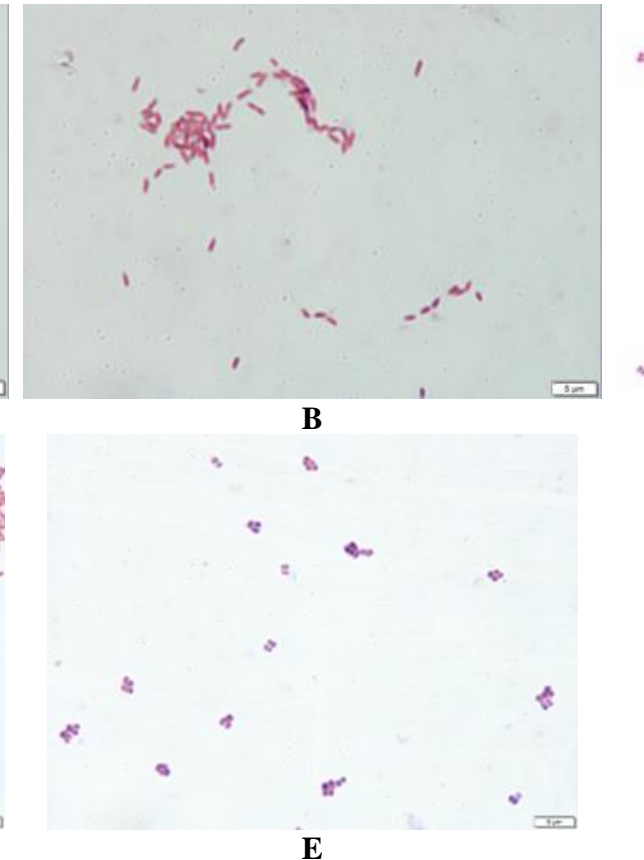

,

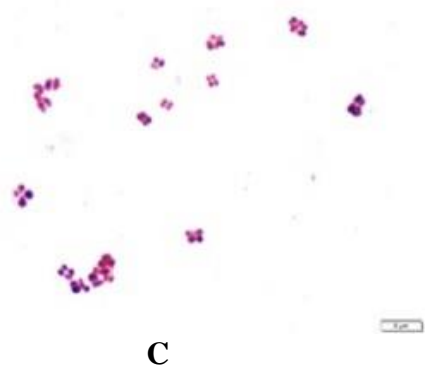

Figure 2. Gram stain of isolated phosphate solubilizing bacteria (A)PSB1, (B)PSB2,(C)PSB3, (D)PSB4 and (E)PSB5

Further sequence analysis on the $16 \mathrm{~S}$ rRNA amplicon using the BLASTn database is shown in Table 1. The analysis of the $16 \mathrm{~S}$ rRNA region revealed these strains exhibited high similarity to Bacillus sp., Pseudomonas oryzyhabitans, Paenibacillus sp. and two strains of Staphylococcus pasteuri. The sequences of strains were deposited into GenBank and its accession number were shown in Table 1. These identities were $100 \%$ matched with BLASTn databases based on their base sequence similarities. All identified isolates have been reported as one of the main microbial communities in the forest soil. Previous research has shown that this community is responsible for keeping the nutrient cycle in the soil stays in balance. Moreover, the isolated Gram-negative Bacillus and Pseudomonas from the rainforest soil have been shown to support crop plant growth and the well-known model plant, Arabidopsis thaliana (Huang et al. 2015). Pseudomonas, on the other hand, decomposes fungal mycelia, which returns nutrients to the soil and is absorbed by plants (Lladó et al. 2017). Meanwhile, Gram-negative
Paenibacillus, a member of the Firmicutes phylum, has been found in a variety of environmental studies, including animals and fish, palm oil waste, and plants. Interestingly, only a few species of the Paenibacillus genus have been isolated from forest soil, especially in the tropical regions (Ina-Salwany et al. 2015; Grady et al. 2016; Chin et al. 2017; Haruna et al. 2017; Huang et al. 2017; Kim et al. 2021). Gram-positive Staphylococcus on the other hand is likely to be found in an animal's intestinal tract instead of the environmental samples. According to previous research, the majority of Staphylococcus bacteria present in the soil are phosphate solubilizing bacteria (Panda et al. 2016; Hii et al. 2020). The isolated bacteria were shown to have antifungal and solubilizing phosphatase in a wide range, proving that they were promising plant growthpromoting bacteria. Since the genera were typically present in the soil and most were reportedly able to solubilize phosphate compounds, all isolated strains obtained from our sample support the existing literature. 
Table 1. Summary of hits on NCBI Database using BLASTn and reported Phosphatase in PDB

\begin{tabular}{|c|c|c|c|c|}
\hline Sample & 16S rRNA NCBI BLASTn & $\begin{array}{c}\text { Identical } \\
(\%)\end{array}$ & $\begin{array}{l}\text { Phosphatases availability in } \\
\text { Protein Data Bank }\end{array}$ & $\begin{array}{c}\text { Strain designation for the isolated } \\
\text { colony (GenBank Acc. No.) }\end{array}$ \\
\hline PSB1 & Bacillus sp. strain JUBYHD3-1 & 100 & Yes (3OT9,2YEQ,1EJJ, 3CWF) & Bacillus sp. PSB01 (MZ675820) \\
\hline PSB2 & $\begin{array}{l}\text { Pseudomonas oryzyhabitans strain } \\
\text { IASSTS7 }\end{array}$ & 100 & Yes (3ZWU,4ALF,4A9V,4F18) & $\begin{array}{l}\text { Pseudomonas oryzyhabitans PSB02 } \\
\text { (MZ675821) }\end{array}$ \\
\hline PSB3 & Staphylococcus pasteuri strain $3 \mathrm{I} 10$ & 100 & Yes $(6 \mathrm{IHT})$ & $\begin{array}{l}\text { Staphylococcus pasteuri } \\
\text { (MZ675822) }\end{array}$ \\
\hline PSB4 & $\begin{array}{l}\text { Paenibacillus sp. strain UFLA01- } \\
923\end{array}$ & 100 & No & $\begin{array}{l}\text { Paenibacillus sp. PSB04 } \\
\text { (MZ675823) }\end{array}$ \\
\hline PSB5 & Staphylococcus pasteuri strain 3I10 & 100 & Yes $(6 \mathrm{IHT})$ & $\begin{array}{l}\text { Staphylococcus pasteuri PSB05 } \\
\text { (MZ675824) }\end{array}$ \\
\hline
\end{tabular}

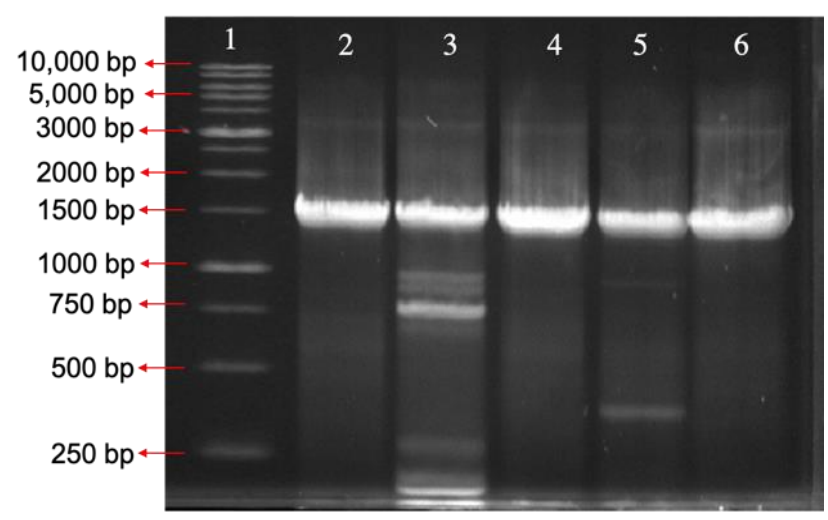

Figure 3. 16S rRNA gene PCR of the isolated colony on a $1 \%$ Agarose Gel; Lane 1: $1 \mathrm{~Kb}$ DNA Ladder, Lane 2: PSB1; Lane 3: PSB2; Lane 4: PSB3; Lane 5: PSB4; Lane 6: PSB5

The isolates and associated reference strains were used to create a phylogenetic tree (Figure 4). The tree is grouped into four clusters, each representing different genera. Cluster A, B, C, and D, corresponds to the Staphylococcus group, Bacillus group, Paenibacillus group, and Pseudomonas group, respectively. Figure 4 shows the genetic tree generated by the neighbor-joining algorithm method, and a similar result was obtained by using the maximum-likelihood algorithm method (data not shown).

Earlier studies have shown that the phosphatase family from Staphylococcus is a promising candidate for antivirulence targeting protein and a reporter in gene expression. Staphylococcus species were also found to be able to effectively dephosphorylate peptides using the phosphate protein crystal structure of Stp1 (du Plessis et al. 2007; Yang et al. 2019). In addition, the class C family of nonspecific acid phosphatase from Staphylococcus also proved to be a promising reporter in protein and gene expression studies due to its simple quantitative and qualitative detection. Meanwhile, bacterial phosphataseencoding genes were also found in the Pseudomonas group. Plant growth was found to be supported by a consortium of Pseudomonas and Bacillus, as well as other genera, particularly in the organic farming system. The coinoculation of Bacillus and Pseudomonas had a synergistic effect on enzymatic activity in the soil and increased the biomass of the microbial population in the plantation soil
(Kumar et al. 2016; Angelina et al. 2020). Furthermore, it was revealed that one of the isolated species belongs to the same genus as Paenibacillus rhizosphaerae, P. amyloticus, $P$. silvae, and $P$. tyrfis. These findings are also consistent with the previous finding in which our isolated strain was categorized under the same group (Rivas et al. 2005). Noteworthy, PSB04 and $P$. silvae strains were both isolated from a similar type of environmental condition, primarily rainforest soil (Huang et al. 2017). Besides, a strain of $P$. tyrfis was also found previously from the tropical mangrove soil in Malaysia although there were differences in the type of soil sampled. Hence, it is reasonable to conclude that the tropical climate is conducive to the growth of this genus (Aw et al. 2016). Although the BLASTn presented genus or even species-level identification, the established phylogenetic tree based on the 16S rRNA gene sequence of the isolates supported the earlier discovery.

Except for Paenibacillus, the phosphatase enzymes for PSB01, PSB02, PSB03 and PSB05 strains were reported to exist (deposited in the Protein Data Bank (PDB) as listed in Table 1). The availability of phosphatase enzymes in PDB indicated that the enzymes from those strains were extensively studied, particularly in their structures and functions (Cavalli et al. 2007). The absence of a phosphatase structure for Paenibacillus (Table 1) indicated that no previous structural studies on the phosphatase from this group and, therefore, contains great potential findings. Nevertheless, with very limited information on its phosphatase enzymes, many strains of Paenibacillus sp. have been previously used as biofertilizer with a consortium of bacterial species and its functional traits was only based on its genome analysis (Khalid et al. 2009; Shtark et al. 2010; Passera et al. 2018). Nevertheless, no studies have been reported on the catalytic and structural properties of phosphatase. As a result, Paenibacillus sp. PSB04, an isolated Paenibacillus sp., was chosen for further investigation.

Firstly, morphological property of Paenibacillus sp. PSB04 was confirmed under SEM. The isolated Paenibacillus sp. PSB04 showed a rod-shaped structure based on the micrograph obtained by SEM (Figure 5) with the length ranging from $1.85 \mu \mathrm{m}$ to $3.45 \mu \mathrm{m}$. Furthermore, the PSB04 strain had the highest specific alkaline phosphatase activity of all the strains previously studied, at 7,378.12 $\mathrm{U} \mathrm{mg}^{-1}$ (Table 2). 
NZ UHDU01000001.1: Staphylococcus petrasii subsp. petrasii strain NCTC13835 whole genome shotgun sequence

$\checkmark$ PSB3 Staphylococcus sp.

NZ UHCZ01000002.1: Staphylococcus devriesei strain NCTC13828 whole genome shotgun sequence

93 NZ RXWW01000004.1:Staphylococcus saccharolyticus strain NCTC 11807 DSM10656 c4 whole genome shotgun sequence

NZ LR134304.1: Staphylococcus schweitzeri strain NCTC13712 chromosome 1

NZ CP035288.1: Staphylococcus epidermidis strain ATCC 14990 chromosome complete genome

NZ CP032159.1: Staphylococcus warneri strain 22.1 chromosome st war 22.1 complete sequence

NZ CP015758.1: Staphylococcus argenteus strain BN75 chromosome

98

NZ AP0185871: Staphylococcus caprae strain JMUB898

$\triangle$ PSB5 Staphylococcus sp.

NZ CP032365.1: Bacillus wiedmannii strain SR52 chromosome complete genome

NZ CP040336.1: Bacillus luti strain FJ

NZ CP049019.1:4795413-4796230 Bacillus tropicus strain AOA-CPS1

9 NZ MACH01000033.1: Bacillus proteolyticus strain TD42 contig128 whole genome shotgun sequence

NZ SDFS01000030.1: Bacillus albus strain PG 26

$\triangle P S B 1$ Bacillus sp.

KT216503.1 Paenibacillus tyrfis strain MSt1 16S ribosomal RNA gene partial sequence|

NZ BCNV01000012.1: Paenibacillus amylolyticus strain Heshi-A3 whole genome shotgun sequence

99 73. KC835077.1 Paenibacillus silvae strain DB13031 16S ribosomal RNA gene partial sequencel

85 KM250108.1 Paenibacillus silvae strain DB13311 16S ribosomal RNA gene partial sequence)

49 NZ MRTP01000005.1: Paenibacillus rhizosphaerae strain FSL R5-0378 NODE 5 length 397257 cov 2.06274 ID 3974 whole genome shotgun sequence

$\triangle P S B 4$ Paenibacillus sp.

100 NZ VDNQ01000010.1: Pseudomonas oryzihabitans strain DE0585 NODE 10 length 1357 cov 227.642195 whole genome shotgun sequence

${ }^{98} \triangle P S B 2$ Pseudomonas sp.

L NZ SULN01000028.1: Pseudomonas rhizoryzae strain ZYY160 contig28 whole genome shotgun sequence

100 NZ AVEL02000008.1: Pseudomonas tremae strain CC1513 contig8.1 whole genome shotgun sequence

- NZ CCYK01000005.1: Pseudomonas massiliensis strain CB1 whole genome shotgun sequence

61 NZ BDAE01000066.1: Pseudomonas luteola NBRC 103146 whole genome shotgun sequence

76 NZ VLKY01000058.1: Pseudomonas duriflava strain CGMCC 1.6858 IQ22DRAFT scaffold00058.58 whole genome shotgun sequence

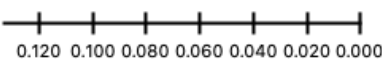

Figure 4. Phylogenetic tree of the isolated PSB. All bootstrap values (expressed as a percentage of 1,000 replications) were shown at branch points 
Table 2. Comparison of enzymatic activity of Paenibacillus sp. PSB04 with some well-studied alkaline phosphatases

\begin{tabular}{lllll}
\hline \multicolumn{1}{c}{ Origin of bacteria } & Type of enzyme & Total activity $(\mathbf{U})$ & Specific activity $\left(\mathbf{U ~ m g}^{-\mathbf{1}}\right)$ & \multicolumn{1}{c}{ Reference } \\
\hline Paenibacillus sp. PSB04 & Crude Enzyme & 1193.37 & 7378.1 & This Study \\
Halomonas sp. 593 & Crude Enzyme & 167.50 & 6700.0 & (Ishibashi et al. 2005, 2011) \\
Shewanella sp. T3-3 & Expressed Enzyme & 5380000.00 & 35.4 & (Aiba et al. 2017) \\
Marine bacterium & Expressed Enzyme & 2595.60 & 12.6 & (Balabanova et al. 2014) \\
Alcaligenes faecalis & Crude Enzyme & 3576.55 & 8.9 & (Behera et al. 2017) \\
Lactobacillus casei 355 & Crude Enzyme & 1876.00 & 3.4 & (Chu et al. 2019) \\
Thermotoga maritima & Expressed Enzyme & 4.00 & 2.0 & (Wojciechowski et al. 2002) \\
\hline
\end{tabular}

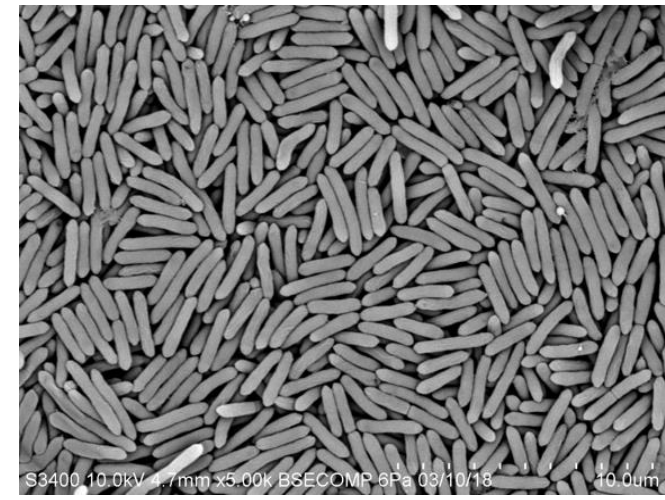

Figure 5. Scanning electron microscopy image of strain Paenibacillus sp. PSB04

Even though the assay used unpurified proteins (crude), the specific activity had a similar activity with the phosphatase activity from Halomonas sp. 593. To note, the activity of crude enzyme does not reflect the real activity of phosphatases PSB04 since the crude enzyme contains various contaminants protein or enzymes (Ishibashi et al. 2005; Obeng et al., 2017). Other enzymes may interfere with the activity of phosphatase in the crude extract. Nevertheless, empirically, the purified enzyme should exhibit higher specific activity as compared to the unpurified one. Budiman et al. $(2011 ; 2018)$ and Razali et al. (2021) reported that the increase of enzyme purity is accompanied by the increase in its specific activity. During purification, antagonist enzymes such as proteases are removed, allowing the protein of interest to be in the best possible state to produce its actual catalytic activity. This implies that the real specific activity of the PSB04 strain is expected to be higher after purification. This, nevertheless, should be experimentally confirmed.

In conclusion, we have isolated and characterized five (5) strains of PSB from the DV tropical rainforest soil. The strains are designated as Bacillus sp. PSB01 (MZ675820), Pseudomonas oryzyhabitans PSB02 (MZ675821), Paenibacillus sp PSB04 (MZ675823) and two strains of Staphylococcus pasteuri PSB03 (MZ675822) and PSB05 (MZ675824). Morphologically, Bacillus sp., Pseudomonas oryzyhabitans, Paenibacillus sp. were rod-like, while Streptococcus pasteuri was spherical shaped. Among these five strains, the phosphatase enzyme from the Paenibacillus group was the least studied and, therefore, was selected for further characterization. For the first time, the current study revealed that the phosphatase enzymatic activity of Paenibacillus sp. PSB04 strain was remarkably higher than that of other reported strains. Uncovering the true potential of the phosphatase is in our best interests and may hold key important prospects, as Paenibacillus was the only one of the five bacteria whose phosphatase enzyme was not documented in the protein data bank, indicating that it is a promising candidate for further research. This is an essential aspect in a further attempt to develop a sustainable consortium of biofertilizers, especially to reduce non-renewable rock phosphate mining.

\section{ACKNOWLEDGEMENTS}

The authors wish to thank Universiti Malaysia Sabah for the research grant GUG0277-2/2018. The authors gratefully acknowledge the Malaysia Public Service Department (PPC 2018) for a PhD scholarship to H.U.L. The authors would like to appreciate Prof. David F. R. P. Burslem and Stevell Lumbasi for their assistance in the field. This study is supported by the Sabah Biodiversity Centre under Access License Project Number 423.

\section{REFERENCES}

Aiba H, Nishiya Y, Ojima Y, Azuma M. 2017. Over-expression, characterization, and modification of highly active alkaline phosphatase from a Shewanella genus bacterium. Biosci Biotechnol Biochem 81 (10): 1994-2001. DOI: 10.1080/09168451.2017.1356217

Alori ET, Glick BR, Babalola OO. 2017. Microbial phosphorus solubilization and its potential for use in sustainable agriculture. Front Microbiol 8 (JUN): 1-8. DOI: 10.3389/fmicb.2017.00971

Angelina E, Papatheodorou EM, Demirtzoglou T, Monokrousos N. 2020. Effects of Bacillus subtilis and Pseudomonas fluorescens inoculation on attributes of the lettuce (Lactuca sativa L.) soil rhizosphere microbial community: The role of the management system. Agronomy 10 (9): 1428. DOI: 10.3390/agronomy 10091428

Arief II, Budiman C, Jenie BS, Andreas E, Yuneni A. 2015. Plantaricin IIA-1 A5 from Lactobacillus plantarum IIA-1A5 displays bactericidal activity against Staphylococcus aureus. Benef Microbes 6 (4): 60313. DOI: 10.3920/BM2014.0064.

Aw YK, Ong KS, Lee LH, Cheow YL, Yule CM, Lee SM. 2016. Newly isolated Paenibacillus tyrfis sp. nov., from Malaysian tropical peat swamp soil with broad spectrum antimicrobial activity. Front Microbiol 7 (MAR): 1-9. DOI: 10.3389/fmicb.2016.00219

Balabanova L, Golotin V, Kovalchuk S, Bulgakov A, Likhatskaya G, Son O, Rasskazov V. 2014. A novel bifunctional hybrid with marine bacterium alkaline phosphatase and far eastern holothurian mannanbinding lectin activities. PLOS ONE 9 (11): e112729. DOI: 10.1371/journal.pone.0112729 
Behera BC, Yadav H, Singh SK, Sethi BK, Mishra RR, Kumari S, Thatoi H. 2017. Alkaline phosphatase activity of a phosphate solubilizing Alcaligenes faecalis, isolated from mangrove soil. Biotechnol Res Innov 1 (1): 101-111. DOI: 10.1016/j.biori.2017.01.003

Berman HM, Westbrook J, Feng Z, Gilliland G, Bhat TN, Weissig H, Bourne PE. 2000. The Protein Data Bank. Nucleic Acids Res 28 (1): 235-242. DOI: $10.1093 /$ nar/28.1.235

Billah M, Khan M, Bano A, Hassan TU, Munir A, Gurmani AR. 2019. Phosphorus and phosphate solubilizing bacteria: Keys for sustainable agriculture. Geomicrobiol J 36 (10): 904-916. DOI 10.1080/01490451.2019.1654043

Bononi L, Chiaramonte JB, Pansa CC, Moitinho MA, Melo IS. 2020. Phosphorus-solubilizing Trichoderma spp. from Amazon soils improve soybean plant growth. Sci Rep 10 (1): 2858. DOI: 10.1038/s41598-020-59793-8

Budiman C, Lindang HU, Cheong BE, Rodrigues KF. 2018. Inhibition and substrate specificity properties of FKBP22 from a psychrotrophic bacterium, Shewanella sp. SIB1. Protein J 37(3): 270-279. DOI: 10.1007/s10930-018-9772-z.

Budiman C, Angkawidjaja C, Motoike H, Koga Y, Takano K, Kanaya S 2011. Crystal structure of N-domain of FKBP22 from Shewanella sp. SIB1: dimer dissociation by disruption of Val-Leu knot. Protein Sci 20 (10): 1755-64. DOI: 10.1002/pro.714.

Cabugao KG, Timm CM, Carrell AA, Childs J, Lu TYS, Pelletier DA, Norby RJ. 2017. Root and rhizosphere bacterial phosphatase activity varies with tree species and soil phosphorus availability in Puerto Rico Tropical Forest. Front Plant Sci 8 (October): 1-14. DOI: 10.3389/fpls.2017.01834

Campagnolla C, Rametsteiner E, Gutierrez D. 2019. Sustainable agriculture and food systems: Towards a Third Agricultura Revolution. From Fome Zero to Zero Hunger 140. DOI: 10.18356/87a6946c-en

Cavalli A, Salvatella X, Dobson CM, Vendruscolo M. 2007. Protein structure determination from NMR chemical shifts. Proc Natl Acad Sci 104 (23): 9615 LP-9620. DOI: 10.1038/s41598-020-59793-8

Chin CFS, Furuya Y, Zainudin MHM, Ramli N, Hassan MA, Tashiro Y, Sakai K. 2017. Novel multifunctional plant growth-promoting bacteria in co-compost of palm oil industry waste. J Biosci Bioeng 124 (5): 506-513. DOI: 10.1016/j.jbiosc.2017.05.016

Chu Y, Yu X, Jin X, Wang Y, Zhao D, Zhang P, Sun G, Zhang Y. 2019 Purification and characterization of alkaline phosphatase from lactic acid bacteria. RSC Adv 9: 354-360. DOI: 10.1039/c8ra08921c

du Plessis E, Theron J, Berger E, Louw M. 2007. Evaluation of the Staphylococcus aureus Class C Nonspecific Acid Phosphatase (SapS) as a reporter for gene expression and protein secretion in gramnegative and gram-positive bacteria. Appl Environ Microbiol 73 (22) 7232-7239. DOI: 10.1128/AEM.01030-07

Grady EN, MacDonald J, Liu L, Richman A, Yuan ZC. 2016. Curren knowledge and perspectives of Paenibacillus: A review. Microb Cell Factories 15 (1): 203. DOI: 10.1186/s12934-016-0603-7

Green JJ, Dawson LA, Proctor J, Duff EI, Elston DA. 2005. Fine roo dynamics in a tropical rain forest is influenced by rainfall. Plant Soil 276 (1-2): 23-32. DOI: 10.1007/s11104-004-0331-3

Haruna E, Zin NM, Adams JM. 2017. Draft genome sequence of an endophytic bacterium, Paenibacillus tyrfis strain SUK123, isolated from Santiria apiculata stem. Genomics Data 14 (August): 44-46. DOI: 10.1016/j.gdata.2017.08.005

Hii YS, San, CY, Lau SW, Danquah MK. 2020. Isolation and characterisation of phosphate solubilizing microorganisms from peat. Biocatalysis Agric Biotechnol 26: 101643. DOI 10.1016/j.bcab.2020.101643

Huang H, Zhang F, Liu M, Cui Y, Sun Q, Zhu J, Zou X, Bao S. 2017. Paenibacillus silvae sp. nov., isolated from a tropical rainforest soil. Int J Syst Evol Microbiol 67 (4): 795-799. DOI: 10.1099/ijsem.0.001608

Huang XF, Zhou D, Guo J, Manter DK, Reardon KF, Vivanco JM. 2015 Bacillus spp. from rainforest soil promote plant growth under limited nitrogen conditions. J Appl Microbiol 118 (3): 672-684. DOI: 10.1111/jam. 12720

Hunter MC, Smith RG, Schipanski ME, Atwood LW, Mortensen DA 2017. Agriculture in 2050: Recalibrating targets for sustainable intensification. BioScience 67 (4): 386-391. DOI: 10.1093/biosci/bix010

Ina-Salwany MY, Hishammuddin H, Zulperi Z, Salema M, Karim M, Natrah FMI. 2015. Elucidating the probiotic potential of Malaysian
Paenibacillus pabuli against Vibrio alginolyticus in Artemia culture. Asian J Agric Res 9 (5): 223-236. DOI: 10.3923/ajar.2015.223.236

Ishibashi M, Oda K, Arakawa T, Tokunaga M. 2011. Cloning, expression, purification and activation by $\mathrm{Na}$ ion of halophilic alkaline phosphatase from moderate halophile Halomonas sp. 593. Protein Expr Purif 76 (1): 97-102. DOI: 10.1016/j.pep.2010.09.013

Ishibashi M, Yamashita S, Tokunaga M. 2005. Characterization of halophilic alkaline phosphatase from Halomonas sp. 593, a moderately halophilic bacterium. Biosci Biotechnol Biochem 69 (6): 1213-1216. DOI: 10.1271/bbb.69.1213

Khalid A, Arshad M, Shaharoona B, Mahmood T. 2009. Plant growth promoting rhizobacteria and sustainable agriculture. In: Khan MS (eds) Microbial Strategies for Crop Improvement. Springer-Verlag, Berlin, Heidelberg. DOI: 10.1007/978-3-642-01979-1

Kim J, Jung HS, Baek JH, Chun BH, Khan SA, Jeon CO. 2021. Paenibacillus silvestris sp. nov., isolated from forest soil. Curr Microbiol 78 (2): 822-829. DOI: 10.1007/s00284-020-02333-4

Komatsuzaki M, Ohta H. 2013. Sustainable agriculture practices. In Designing our Future, United Nations. DOI: 10.18356/4f898e93-en

Kumar M, Mishra S, Dixit V, Kumar M, Agarwal L, Chauhan PS, Nautiyal CS. 2016. Synergistic effect of Pseudomonas putida and Bacillus amyloliquefaciens ameliorates drought stress in chickpea (Cicer arietinum L.). Plant Signaling Behav 11 (1): e1071004. DOI: 10.1080/15592324.2015.1071004

Liu X, Li Q, Li Y, Guan G, Chen S. 2019. Paenibacillus strains with nitrogen fixation and multiple beneficial properties for promoting plant growth. PeerJ 7: e7445. DOI: 10.7717/peerj.7445

Lladó S, López-Mondéjar R, Baldrian P. 2017. Forest soil bacteria: Diversity, involvement in ecosystem processes, and response to global change. Microbiol Mol Biol Rev 81 (2): e00063-16. DOI: 10.1128/MMBR.00063-16

Mogollón JM, Beusen AHW, van Grinsven HJM, Westhoek H, Bouwman AF. 2018. Future agricultural phosphorus demand according to the shared socioeconomic pathways. Glob Environ Change 50: 149-163. DOI: $10.1016 /$ j.gloenvcha.2018.03.007

Mohamed AE, Nessim MG, Abou-el-seoud II, Darwish KM, Shamseldin A. 2019. Isolation and selection of highly effective phosphate solubilizing bacterial strains to promote wheat growth in Egyptian calcareous soils. Bull Natl Res Centre 43 (1): 203. DOI: 10.1186/s42269-019-0212-9

Nautiyal CS. 1999. An efficient microbiological growth medium for screening phosphate solubilizing microorganisms. FEMS Microbiol Lett 170 (436): 265-270. DOI: 10.1111/j.1574-6968.1999.tb13383.x

Obeng EM, Budiman C, Ongkudon CM. 2017. Identifying additives for cellulase enhancement-A systematic approach. Biocatalysis Agric Biotechnol 11: 67-74. DOI: 10.1016/j.bcab.2017. 06.006

Panda B, Rahman H, Panda J. 2016. Phosphate solubilizing bacteria from the acidic soils of Eastern Himalayan region and their antagonistic effect on fungal pathogens. Rhizosphere 2: 62-71. DOI: 10.1016/j.rhisph.2016.08.001

Passera A, Marcolungo L, Casati P, Brasca M, Quaglino F, Cantaloni C, Delledonne M. 2018. Hybrid genome assembly and annotation of Paenibacillus pasadenensis strain R16 reveals insights on endophytic life style and antifungal activity. PLoS ONE 13 (1). DOI: 10.1371/journal.pone.0189993

Pathania P, Rajta A, Singh PC, Bhatia R. 2020. Role of plant growthpromoting bacteria in sustainable agriculture. Biocatalysis Agric Biotechnol 30: 101842. DOI: 10.1016/j.bcab.2020.101842

Pepper IL, Gerba CP. 2015. Chapter 8 - Environmental Sample Collection and Processing. In: Pepper IL, Gerba CP, Gentry TJ (eds) Environmental Microbiology Academic Press, San Diego. DOI: 10.1016/B978-0-12-394626-3.00001-6

Razali R, Budiman C, Kamaruzaman KA, Subbiah VK. 2021. Soluble expression and catalytic properties of codon-optimized recombinant bromelain from MD2 pineapple in Escherichia coli. Protein J 1-13. DOI: 10.1007/s10930-021-09974-9.

Riutta T, Malhi Y, Kho LK, Marthews TR, Huaraca Huasco W, Khoo M, Tan S, Turner E, Reynolds G, Both S, Burslem DF. 2018. Logging disturbance shifts net primary productivity and its allocation in Bornean tropical forests. Glob Change Biol 24: 2913-2928. DOI: $10.1111 / \mathrm{gcb} .14068$

Rivas R, Gutiérrez C, Abril A, Mateos PF, Martínez-Molina E, Ventosa A, Velázquez E. 2005. Paenibacillus rhizosphaerae sp. nov., isolated from the rhizosphere of Cicer arietinum. Int J Syst Evol Microbiol 55 (3): 1305-1309. DOI: 10.1099/ijs.0.63513-0 
Sabat AJ, van Zanten E, Akkerboom V, Wisselink G, van Slochteren K, de Boer R F, Hendrix R, Friedrich A W, Rossen JWA, Kooistra-Smid AMD. 2017. Targeted next-generation sequencing of the 16S-23S rRNA region for culture-independent bacterial identification increased discrimination of closely related species. Sci Rep 7 (1) 3434. DOI: $10.1038 / \mathrm{s} 41598-017-03458-6$

Sánchez-Cruz ND, Meza-Contreras JC, Escalante FME, MacíasRodríguez ME, Salcedo-Perez E, González-García Y. 2020. Phosphate solubilization and indole-like compounds production by bacteria isolated from forest soil with plant growth promoting activity on pine seedlings. Geomicrobiol J 37 (10): 909-918. DOI:10.1080/01490451.2020.1797945

Sharma SB, Sayyed RZ, Trivedi MH, Gobi TA. 2013. Phosphate solubilizing microbes: Sustainable approach for managing phosphorus deficiency in agricultural soils. SpringerPlus 2 (1): 1-14. DOI 10.1186/2193-1801-2-587

Song J, Min L, Wu J, He Q, Chen F, Wang, Y. 2021. Response of the microbial community to phosphate-solubilizing bacterial inoculants on Ulmus chenmoui Cheng in Eastern China. PLOS ONE 16 (2): e0247309. DOI: 10.1371/journal.pone.0247309

Shtark OY, Borisov AY, Zhukov VA, Provorov NA, Tikhonovich IA 2010. Intimate associations of beneficial soil microbes with hos plants. In: Dixon GR, Tilston EL (eds) Soil Microbiology and Sustainable Crop Production. Springer, Dordrecht. DOI: 10.1007/978-90-481-9479-7

Stecher G, Tamura K, Kumar S. 2020. Molecular Evolutionary Genetics Analysis (MEGA) for macOS. Mol Biol Evol 37 (4): 1237-1239. DOI: $10.1093 / \mathrm{molbev} / \mathrm{msz} 312$

Suliasih S. 2005. Isolation and identification of phosphate solubilizing and nitrogen fixing bacteria from soil in Wamena Biological Garden,
Jayawijaya, Papua. Biodiversitas J Biol Divers 6 (5): 175-177. DOI: 10.13057/biodiv/d060307

Tang A, Haruna AO, Majid NMA, Jalloh MB. 2020. Potential PGPR properties of cellulolytic, nitrogen-fixing, phosphate-solubilizing bacteria in rehabilitated tropical forest soil. Microorganisms 8 (3): 442. DOI: $10.3390 /$ microorganisms 8030442

Taylor EB, Williams MA. 2010. Microbial protein in soil: Influence of extraction method and $\mathrm{C}$ amendment on extraction and recovery. Microb Ecol 59 (2): 390-399. DOI: 10.1007/s00248-009-9593-x

Tin HS, Palaniveloo K, Anilik J, Vickneswaran M, Tashiro Y, Vairappan CS, Sakai K. 2017. Impact of land-use change on vertical soil bacterial communities in Sabah. Microb Ecol 75 (2): 459-467. DOI: 10.1007/s00248-017-1043-6

Tripathi BM, Kim M, Singh D, Lee-Cruz L, Lai-Hoe A, Ainuddin AN, Go R, Rahim RA, Husni MH, Chun J, Adams JM. 2012. Tropical soil bacterial communities in Malaysia: $\mathrm{pH}$ dominates in the equatorial tropics too. Microb Ecol 64 (2): 474-84. DOI: 10.1007/s00248-0120028-8

Ushio M, Kitayama K, Balser TC. 2010. Tree species effects on soil enzyme activities through effects on soil physicochemical and microbial properties in a tropical montane forest on Mt. Kinabalu, Borneo. Pedobiologia 53 (4): 227-233. DOI: 10.1016/j.pedobi.2009.12.003

Wojciechowski CL, Cardia JP, Kantrowitz ER. 2002. Alkaline phosphatase from the hyperthermophilic bacterium T. maritima requires cobalt for activity. Protein Sci 11 (4): 903-911. DOI:10.1110/ps.4260102

Yang T, Liu T, Gan J, Yu K, Chen K, Xue W, Lan L, Yang S, Yang C. 2019. Structural insight into the mechanism of Staphylococcus aureus Stp1 Phosphatase. ACS Infect Dis 5 (6): 841-850. DOI: 10.1021/acsinfecdis.8b00316 